\title{
Bioactive proteins and peptides isolated from Chinese medicines with pharmaceutical potential
}

\author{
Kam Lok Wong ${ }^{1}$, Ricky Ngok Shun Wong ${ }^{2}$, Liang Zhang ${ }^{1}$, Wing Keung Liu ${ }^{3}$, Tzi Bun NG ${ }^{3}$, Pang Chui Shaw ${ }^{4}$, \\ Philip Chi Lip Kwok', Yau Ming Lai ${ }^{6}$, Zhang Jin Zhang ${ }^{1}$, Yanbo Zhang ${ }^{1}$, Yao Tong ${ }^{1}$, Ho-Pan Cheung ${ }^{1}$, Jia Lu ${ }^{1}$ \\ and Stephen Cho Wing Sze ${ }^{1 *}$
}

\begin{abstract}
Some protein pharmaceuticals from Chinese medicine have been developed to treat cardiovascular diseases, genetic diseases, and cancer. Bioactive proteins with various pharmacological properties have been successfully isolated from animals such as Hirudo medicinalis (medicinal leech), Eisenia fetida (earthworm), and Mesobuthus martensii (Chinese scorpion), and from herbal medicines derived from species such as Cordyceps militaris, Ganoderma, Momordica cochinchinensis, Viscum album, Poria cocos, Senna obtusifolia, Panax notoginseng, Smilax glabra, Ginkgo biloba, Dioscorea batatas, and Trichosanthes kirilowii. This article reviews the isolation methods, molecular characteristics, bioactivities, pharmacological properties, and potential uses of bioactive proteins originating from these Chinese medicines.
\end{abstract}

\section{Background}

The therapeutic potential of proteins from Chinese medicine $(\mathrm{CM})$ has not realized without extensive research. Nevertheless, according to a report from BCC Research LLC. in October 2013, the global market for protein pharmaceuticals was predicted to be $\$ 136.7$ billion in 2013 and to increase to $\$ 179.1$ billion in 2018, with an average annual growth rate of approximately 5.6\% from 2013 to 2018 [1]. Many protein pharmaceuticals are available for treating rheumatoid arthritis, coronary artery thrombosis, multiple sclerosis, and chronic lymphocytic leukemia [2-4].

Quality control of Chinese medicinal herbs is a challenge because the therapeutic effects of medicinal herbs are subject to by different factors, such as geographical constraints, soil mineral content, temperature, and humidity. Moreover, guidelines for quality control are not readily available. The 2002 guidelines of the European Agency for the Evaluation of Medicinal Products for good agricultural practice does not include a standardization for materials of herbal origin [5]. However, protein or peptide pharmaceuticals derived from $\mathrm{CM}$ can be produced through recombinant technology, which can minimize batch-to-

\footnotetext{
* Correspondence: stephens@hku.hk

${ }^{1}$ School of Chinese Medicine, LKS Faculty of Medicine, The University of Hong Kong, 10 Sassoon Road, Pokfulam, Hong Kong Special Administrative Region, China

Full list of author information is available at the end of the article
}

batch variations in quality [6]. Additionally, drug delivery systems, such as polyethylene glycol (PEG) and nanocarriers, could promote the clinical efficacy of protein drugs from CM $[7,8]$.

This article aims to review the bioactive proteins and peptides isolated from $\mathrm{CM}$ with potential for clinical use.

\section{Methodology}

A variety of databases, including Google Scholar/Google, PubMed, Science direct, CINAHL Plus, Cochrane Library, Global health, ISI Web of Knowledge, Chinese database CNKI, CQVIP, and CJFD, were searched to get the information about protein drugs derived from Chinese medicine with the following key words: "Chinese medicine", "natural products" together with "protein", "peptide", "protein pharmaceuticals", "peptide pharmaceuticals" or "protein drugs". Furthermore, information on the website of WHO was also collected. For the bioinformatics information of protein, the protein structure, sequence alignment or both, were obtained from the Molecular Modeling Database (MMDB) and Conserved Domain Database (CDD) on the website of NCBI by searching their scientific names of species and their protein names. All data were further analyzed to obtain the information about the current progress in research on promising protein/peptide drugs isolated from CM. 
Bioactive proteins and peptides from Chinese medicines Raw and fresh CM materials, rather than dried, processed, or powdered materials, are often used to obtain bioactive peptides to prevent protein denaturation and degradation from processing $[9,10]$. Some isolated proteins have been approved by the Food and Drug Administration (FDA) of the United States for clinical use or clinical trials (Table 1).

\section{Animal proteins and peptides \\ Hirudin from Hirudo spp. (leech)}

Hirudin, from the saliva of Hirudo spp., was used in CM to enhance blood (xue) circulation [11]. Hirudin was a potent natural inhibitor of thrombin [12] via formation of a hirudin-thrombin complex $[13,14]$. Although hirudin was isolated and purified from a complex salt-containing solution with hydrophobic chromatography [15], it was difficult to extract large amounts of hirudin from natural sources. Hirudin is approximately $7.1 \mathrm{kDa}$ and is composed of 65 amino acids, including a compact $\mathrm{N}$-terminal domain containing three S-S bonds and a C-terminal domain that is disordered in un-complexed hirudin $[16,17]$. Figure 1 illustrates the interaction of hirudin with napsagatran $[13,18]$.

In contrast to antithrombin III, hirudin inhibited thrombin [13], for treating blood coagulation disorders such as venous thrombosis, coronary thrombosis, and stroke [19]. Recombinant or synthetic hirudin would be of great clinical value because only low yields of hirudin could be extracted from leeches. Bivalirudin is a 20 -amino-acid-long synthetic peptide engineered as an analogue of hirudin and has advantages over heparin [20]. The required dosage of bivalirudin was lower, and the anticoagulation mechanism did not depend on intrinsic factors, as was the case of heparin [21]. Bivalirudin was approved by the FDA in December 2000 and was frequently used as an anticoagulant in percutaneous coronary intervention [22,23]. A pharmacokinetic study of recombinant hirudin with chromogenic substrate assay and ELISA demonstrated that its half-life in the plasma in male Sprague Dawley rats was less than $1 \mathrm{~h}$ [24].

Additionally, hirudin possessed anti-proliferative activity toward human ovarian cancer cells and tongue squamous cell cancer cells with a synergistic effect with adriamycin in vitro [25-27].

\section{Fibrinolytic enzymes from Eisenia fetida (earthworm)}

Eisenia fetida (earthworm) was used in CM as an antipyretic and anesthetic for treating asthma and hypertension [28]. Ten fibrinolytic enzymes categorized into four groups had been isolated from Eisenia fetida [9]. The total number of fibrinolytic enzymes from Eisenia fetida was controversial, because the chemical charactersticis, including the full-length amino acid sequences, were not well studied [29]. Seven fibrinolytic enzymes, EFE-a, EFE-b, EFE-c, EFE-d, EFE-e, EFE-f, and EFE-g, were isolated and purified from lyophilized crude powder of earthworm fibrinolytic enzymes by ATKA Purifier, FPLC, and relative pre-packing chromatography columns [30]. These enzymes were crystallized with the hanging-drop vapordiffusion method [30].

EFE-a, d, and e are approximately $2.4 \mathrm{kDa}$ with isoelectric points (pI) of 3.46, 3.68, 3.62, respectively [30]. EFE-b, c, and g are approximately $3.0 \mathrm{kDa}$ with pI of $3.50,3.50,3.46$, respectively [30]. EFE-f has a molecular weight of about $2.3 \mathrm{kDa}$ with a pI of 3.94 [30]. Figure 2 shows the interaction of a fibrinolytic enzyme with $\mathrm{N}$ acetyl-beta-D-glucosaminylamine [18,31,32].

Fibrinolytic enzymes exhibited different fibrinolytic activities. EFE-a possessed fibrinolytic activity, with plasminogen-activating activity, which was not present in the other fibrinolytic enzymes [30]. Moreover, earthworm fibrinolytic enzymes exhibit antitumor activity against several hepatoma cell lines in vitro and in vivo [33], which were potential therapeutic enzymes for hepatomas [34]. After chemically conjugated with human serum albumin fragments, the enzymes lost their antigenicity and acquired resistance to inactivation by protease inhibitors [35]. However, maintenance of enzymatic activity within the body and cleave-site specificity of the enzyme were critical challenges to the practical use of earthworm fibrinolytic enzymes [34].

\section{An antiepilepsy protein (AEP) from Mesobuthus martensii (Chinese scorpion)}

Scorpions, especially their tails, were used in CM for the treatment of convulsion and epilepsy [36]. An antiepilepsy protein (AEP) was isolated from the venom of the Chinese scorpion Mesobuthus martensii by chromatography, including CM-Sephadex C-50 chromatography, gel filtration on Sephadex G-50, and DEAE-Sephadex A-50 chromatography. The homogeneity of AEP was demonstrated using $\mathrm{pH} 4.3$ polyacrylamide-disc-gel electrophoresis, focusing electrophoresis, and SDS/polyacrylamide-disc-gel electrophoresis [37]. AEP is an 8.3-kDa peptide composed of 61 amino acids, and is derived from an 85-amino-acid precursor. The mature protein contains eight cysteine residues that form four disulfide bonds [38].

AEP exhibited antiepileptic activity by binding to the presynaptic membrane protein synaptosomal-associated protein 25 and the glutamate receptor $\mathrm{N}$-methyl-D-aspartate. Hemorrhagic and toxic activities were not detected in AEP [39]. AEP $(28 \mathrm{mg} / \mathrm{kg})$ slightly decreased heart rate in mice without toxicity [37]. The AEP relieved seizures induced by the coriaria lactone without reported side effects in mice $[38,40]$. The gene encoding AEP was successfully cloned, sequenced, and expressed in a eukaryotic system, providing a rapid method for producing the protein for further mechanistic study [38,39]. Figure 3 shows the alignment of conserved domains in AEP [41]. 


\section{Table 1 Bioactive proteins isolated from Chinese medicine and their reported pharmacological effects}

\section{Peptides/protein from medicinal animals}

Hirudo spp. (Leeches)

Eisenia fetida (Earthworm)

Mesobuthus martensii (Chinese scorpion)

\section{Peptides/Protein from medicinal fung}

Cordyceps militaris

is

Poria cocos (Schw.) Wolf

\section{Peptides/proteins from medicinal herbs}

Viola tricolor

Momordica cochinchinensis seeds (Mubiezhi)

\section{Pharmacologically active proteins or peptides}

Hirudin

Earthworm fibrinolytic enzyme

Anti-epilepsy protein (8.3 kDa)

Lectin designated as CML $(31 \mathrm{kDa})$

Cordymin (10.9 kDa)

Protease designated CMP (12 kDa)

Ling Zhi-8 (12.4 kDa protein)

Lectin (a 18-kDa protein)

P. cocos immunomodulatory protein (35.6 kDa) (PCP)

Cyclotides

Cochinin B (28 kDa ribosome inactivating protein)

MCoCC-1 (a 33 amino acid long peptide)

Chymotrypsin inhibitor designated as MCoCl (7.5 kDa)

\section{Pharmacological effects}

Anti-coagulation activity through inhibition of thrombin activity $[13,14]$ Anti-proliferative activity toward human ovarian and tongues squamous cancer cells [24-27]

Anti-cancer activity against hepatoma in vitro and in vivo [33]

Anti-epilepsy activity in mice in vivo $[36,37]$

Haemagglutinating activity in mouse and rat erythrocytes

Mitogenic activity on mouse splenocytes [43]

Anti-fungal activity through inhibition of mycelial growth in vitro [44] Inhibitory effect on HIV-1 reverse transcriptase in vitro [42]

Anti-cancer activity against MCF-7 breast cancer cells in vitro [42]

Anti-fungal activity in vitro [44]

Anti-cancer activity against MCF-7 breast cancer cells and bladder cancer 5637 cells in vitro [44]

Immuno-modulatory activity through inducing maturation of human monocyte-derived dendritic cells and stimulating IL2 and IFN- $\gamma$ secretion from CD4 ${ }^{+}$and $C D 8^{+} T$ cells [52], [53]

Anti-cancer activity against lung carcinoma

cell growth in vitro and in vivo $[55,56]$

Haemagglutinating activity and mitogenic activity towards BALB/c mouse splenocytes [49]

Anti-cancer activity against leukemia (L1210 and M1) cells and hepatoma (HepG2) cells [54]

Immunomodulatory activity through activating mouse peritoneal macrophages (RAW 264.7) [60]

Anti-cancer activity against human cancer cells U251, MDA-MB-231, A549, DU145 and BEL-7402 in vitro [63]

Anti-cancer activity against human cervical epithelial carcinoma (HeLa), human embryonic kidney (HEK293) and human small cell lung cancer (NCl-H187) cell lines in vitro [69]

Anti-cancer activity against human melanoma cell line (MM96L) in vitro $[67,71]$

Anti-oxidative activity through activation of glutathione-S-transferase and superoxide dismutase in vitro [71] 


\section{Table 1 Bioactive proteins isolated from Chinese medicine and their reported pharmacological effects (Continued)}

Viscum album (Chinese mistletoe)

Lectin designated as $\mathrm{CM}-1(55 \mathrm{kDa})$

Lectin designated as ACML-55

Novel protein $(19.7 \mathrm{kDa})$

Narcissus tazetta lectin $(26 \mathrm{kDa})$

Narcissus tazetta var. chinenesis

Smilax glabra rhizomes (Tufuling)

Ginkgo biloba seeds (Yinxing)

Dioscorea batata

Trichosanthes kirilowii
Dioscorin $(32 \mathrm{kDa})$

Smilaxin $(30 \mathrm{kDa})$

Ginkbilobin (13 kDa)

Trichosanthin (247 amino acid long peptide)
Immunomodulatory activity through stimulating the proliferation of mouse splenocytes, splenic lymphocytes, bone marrow

cells and macrophages in vitro [67]

Anti-cancer activity against CLY colon cancer cells and HT-29

colorectal cancer cells in vivo and in vitro through down-regulation of micro-RNA miR-135a \& b expression [73]

Immunomodulatory activity through enhancing both antigen specific activation and proliferation of CD4+ and CD8+ T cells as well as number of tumor antigen specific CD8+ T cells [74]

nhibitory effect on cholesterol biosynthesis in

Chinese hamster oocytes in vitro [78]

Antiviral activity against human syncytial virus (RSV), influenza A and influenza B viruses [80]

Immunopotentiating activity through inducing gene expression of IL-1ßand TNF-a in splenocytes and macrophages in vivo [81]

Immuno-stimulating activity in vitro [83]

Anti-cancer activity against MBL2 and PU5 cells in vitro [83] Inhibitory effect on HIV-1 reverse transcriptase in vitro [83]

Anti-fungal activity against Botrytis cinerea, Mycosphaerella arachidicola, Fusarium oxysporum, Rhizoctonia solani, and Coprinus comatus [85]

Antibacterial activity against Staphylococcus aureus, Pseudomonas aeruginosa, and Escherichia coli [85]

Inhibitory effect on HIV-1 reverse transcriptase [85]

Immuno-modulatory activity through inhibiting proliferation of murine splenocytes [85]

Carbonic anhydrase activities [90]

Trypsin inhibitory activities [90]

Potential airway protective effects on A549 human airway epithelium cells [91]

Anti-oxidant properties reflected from DPPH and hydroxyl radicals scavenging effects [93]

Immuno-modulatory activity in vitro and in vivo [94,95]

Anti-HIV activity through inhibition of serum HIV-1 p24 antigen levels and increase CD4 ${ }^{+} \mathrm{T}$ cell count in HIV-1 infected patients [108,109]

Antiviral activity against hepatitis B virus $[110,111]$ 

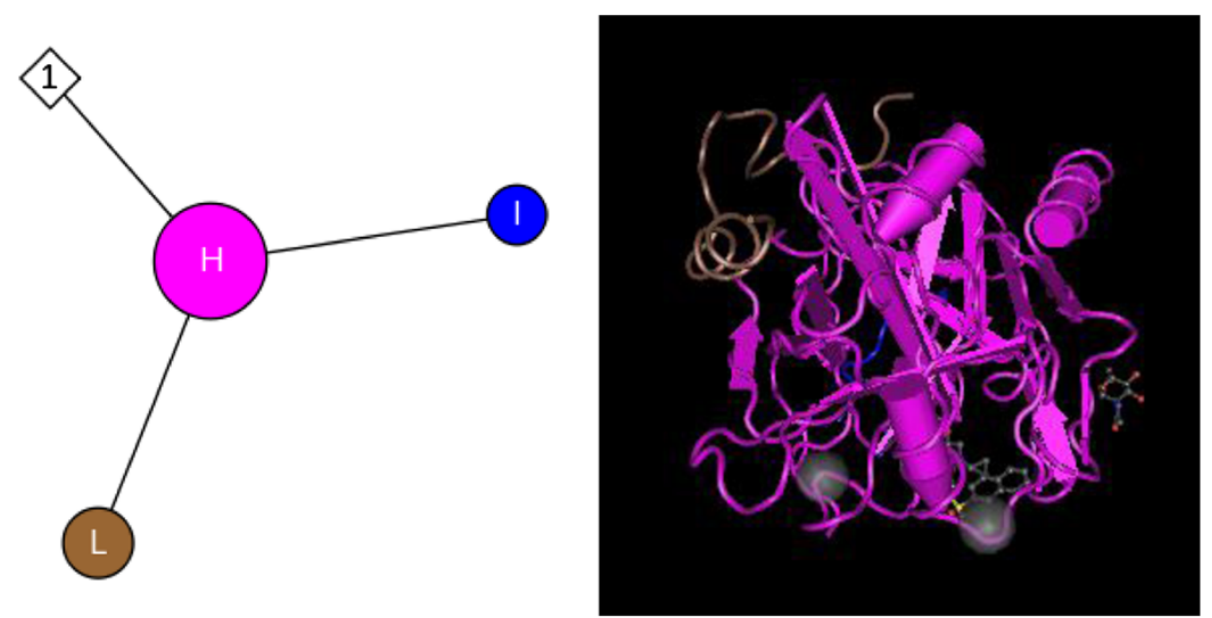

Figure 1 Molecules and interactions of hirudin. $H$, chain $H$ of human thrombin; I, hirudin variant-1; L, chain $L$ of Human thrombin. 1, Napsagatran.

\section{Fungal proteins and peptides}

\section{Lectin and cordymin from Cordyceps militaris}

C. militaris is a less expensive substitute for the mushroom Cordyceps sinensis (Dong Chong Xia Cao) with different pharmacological properties, including hemagglutinating activity, antifungal properties, and antiproliferative properties [42-44].

A lectin (CML) was isolated and purified from the crude protein extract of $C$. militaris by gel-filtration chromatography on a Sephadex G-75 affinity fetuin-agarose column and dialysis [43]. Purified cordymin was obtained with ion-exchange chromatography of the aqueous extract on SP-Sepharose and Mono S, and gel filtration on Superdex 75 by fast protein liquid chromatography (FPLC) [42]. Another anti-fungal and anti-cancer $C$. militaris protein (CMP), was isolated by anion-exchange chromatography on a DEAE-Sepharose column [44].
CML is approximately $31 \mathrm{kDa}$ and contains the $\mathrm{N}$ terminal amino acid sequence SYDADXQRVXNDKGIXND (the " $\mathrm{X}$ " residue could not be identified), which has low homology compared with the lectins from other mushrooms, such as Marasmius oreades, Laetiporus sulphureus and Polyporus squamosus [43]. Moreover, the secondary structure of CML contains $27 \% \alpha$-helix, $12 \% \beta$-sheets, $29 \%$ $\beta$-turns, and $32 \%$ random-coil structures, which is different from the lectins isolated from other mushrooms, such as Marasmius oreades, Laetiporus sulphureus and Polyporus squamosus [43]. Cordymin is an approximately $10.9-\mathrm{kDa}$ peptide, isolated from $C$. militaris, and its $\mathrm{N}$-terminal sequence is AMAPPYGYRTPDA which is not similar to other peptides in the GeneBank database [42]. Another isolated peptide, $C$. militaris protein $(\mathrm{CMP})$ is a $12-\mathrm{kDa}$ peptide and its pI is 5.1 [44]. Moreover, two parts of the CMP sequence (VSXXGDSGVGGN and NAFNDYTFK) possess
(A)

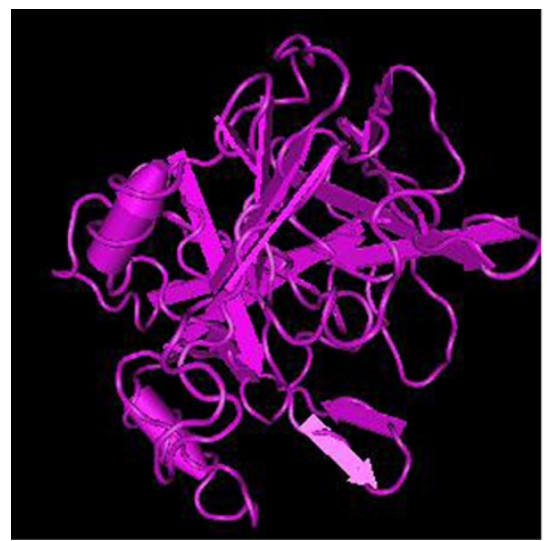

(B)

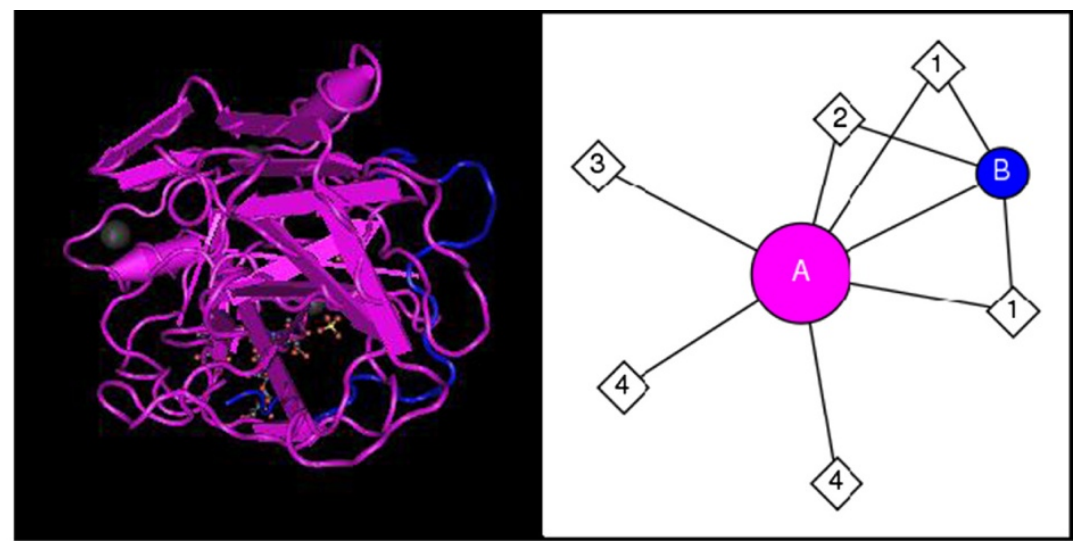

Figure 2 Molecules and interactions of fibrinolytic enzyme. (A), fibrinotic enzyme component $A$; (B), fibrinotic enzyme component B; $A$, chain A of fibrinotic enzyme component B; B, chain B of fibrinotic enzyme component B; 1, N-Acetyl-beta-D-glucosaminylamine; 2 , alpha-L-Fucose; $3 \mathrm{Mg}^{2+} ; 4$, sulfate ion and alpha-D-mannose. 
more than $70 \%$ identity to Rab family GTPases from Entamoeba histolytica and exodeoxyribonuclease $\mathrm{V}$ alpha chain from Haemophilus influenza [44].

CML demonstrated hemagglutinating activity in mouse and rat erythrocytes by specifically binding sialoglycoproteins, and exerted mitogenic activity on mouse splenocytes [43]. Cordymin inhibited not only mycelial growth of numerous fungi, including Bipolaris maydis, Rhizoctonia solani, and Mycosphaerella arachidicola, but also HIV-1 reverse transcriptase and the proliferation of MCF-7 breast cancer cells [42]. CMP could be inhibited by serine protease inhibitors, exhibited an antifungal effect on the growth of Fusarium oxysporum at a minimum concentration of $1.6 \mu \mathrm{M}$, and had antiproliferative effects on human breast cancer MCF-7 cells ( $\mathrm{IC}_{50}$ of $9.3 \mu \mathrm{M})$ and bladder cancer 5637 cells $\left(\mathrm{IC}_{50}\right.$ of $\left.8.1 \mu \mathrm{M}\right)$ [44]. Cordymin prevented osteopenia in diabetic rats by significant up-regulation of bone mineral content and bone mineral density [45].

\section{Ling Zhi-8 and lectin from Ganoderma}

Ganoderma (Ling Zhi) contains a rich content of bioactive constituents and exhibits diverse pharmacological effects, such as anticancer activity, immunomodulatory activity, hypoglycemic action, and hepatoprotection [46]. Moreover, Ganoderma capense (Lloyd) Teng was used to tonify the body and improve mental function [47]. Several bioactive peptides have been purified from Ganoderma, including Ling Zhi-8 (LZ-8) and Ganoderma capense lectin (GCL) $[46,48]$.

LZ-8 (12.4-kDa) was isolated from Ganoderma lucidum by Sephadex G-75 column and DEAE-Sephadex A-25 column chromatography, and dialysis, and was characterized by electrophoretic techniques [49,50]. Additionally, an 18-
kDA lectin from Ganoderma capense (Lloyd) Teng, GCL, was purified by column chromatography on Q-Sepharose and Mono S and gel filtration on a Superdex 75 HR 10/30 column with an AKTA Purifier [49,50].

LZ-8 is a $12-\mathrm{kDa}$ polypeptide consisting of 110 amino acid residues with an acetylated amino terminus $[49,50]$. The molecular mass of GCL is $18 \mathrm{kDa}$, and its N-terminal sequence displays slight similarity to a lectin from Ganoderma lucidum and fungal immunomodulatory proteins from Flammulina velutipes, Volvariella volvacea $[49,50]$. The crystal structure of LZ-8 (Figure 4) supplies a basis to study its bioactive function [18,51]. The C-terminal FNIII domain possessed the immunoglobulin-like $\beta$-sandwich fold to recognize its target including cytohormones, cell adhesion molecules, cytokine receptors, molecular chaperones and carbohydrate binding domains [51].

Recombinant LZ-8 (rLZ-8) protein induced maturation of human monocyte-derived dendritic cells, which was involved in initiating an antigen-specific $\mathrm{T}$ lymphocyte response, by activating the NFKB and MAPK pathways [52]. rLZ-8 also stimulated $\mathrm{CD}^{+}$and $\mathrm{CD}^{+}{ }^{+} \mathrm{T}$ cells to secrete IL2 and IFN- $\gamma$ [53]. GCL exhibited hemagglutinating activity, mitogenic activity toward BALB/c mouse splenocytes, and antiproliferative activity toward leukemia (L1210 and M1) cells and hepatoma (HepG2) cells [54]. rLZ-8 could activate dendritic cells via TLR 4 to strength the effectiveness of anti-cancer vaccine [55]. LZ-8 prohibited lung carcinoma cell growth in vitro and in vivo by regulating p53 [56], and rLZ-8 promoted endoplasmic reticulum stress and the ATF4-CHOP pathway to induce cell death of SGC-7901 human gastric cancer cells via autophagy in vitro [57]. Moreover, rLZ-8 enhanced the immune response and increased the amount of white blood cells to relieve cyclophosphamide-induced leukopenia [58]. 


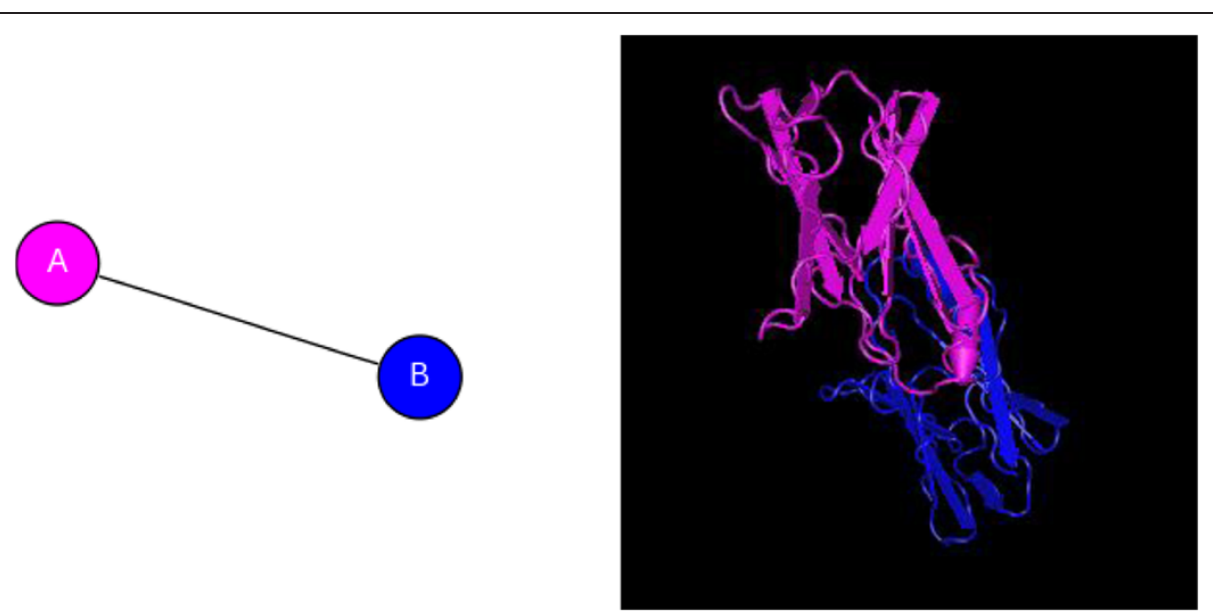

Figure 4 Crystal structure of LZ-8. A, Chain A of LZ-8; B, Chain B of LZ-8.

An immunomodulatory protein (PCP) from Poria cocos

Poria cocos (Fu Ling) reportedly possessed anti-aging, anticancer, and immunomodulatory properties [59]. An immunomodulatory protein (PCP) was isolated and purified from the dried sclerotium of $P$. $\operatorname{cocos}$ (Schw.) Wolf with DE-52 cellulose and gel-filtration chromatography, and was characterized by chromatography and electrophoresis [60]. PCP (35.6 kDa) is a disulfide-linked heterodimeric glycoprotein consisting of 14.3 and $21.3 \mathrm{kDa}$ subunits with $\mathrm{N}$ - and O-glycosylation [60]. The full-length cDNA sequence of PCP has 807 base pairs and the coding region is 579 base pair encoded 194 amino acids which provides an opportunity to express the recombinant [61].

PCP stimulated mouse peritoneal macrophages (RAW 264.7 ) by interacting with toll-like receptor 4 and subsequently activating the $\mathrm{NF}_{\kappa} \mathrm{B}$ signaling pathway [60]. Oral administration of PCP reduced the production of serum total IgG1 and OVA-specific IgG1, as well as up-regulated the serum OVA-specific IgG2a and splenic Th1-related cytokine and down-regulated IL-4 and IgE levels in atopic dermatitis mice [61]. Further studies on PCP will elucidate its modulatory capacity to reveal the pharmaceutical potential and clinical value.

\section{Herbal proteins and peptides \\ Cyclotides (VTCs) from Viola tricolor}

Viola tricolor was used in CM for heat (re) dissipation, detoxification, and cough relief [62]. Recently, 14 cytotoxic cyclotides (VTCs) were purified and characterized from dry whole $V$. tricolor by the solvent extraction technique, column chromatography with macroporous resin (D 101), polyamide (100-200 mesh), reverse phase C18 (40-63 $\mu \mathrm{m})$, and Sephadex LH-20 (25-100 $\mu \mathrm{m})$, thin layer chromatography, and high performance liquid chromatography [63]. Additionally, TLC was used to detect the products during the procedure [63].
Cyclotides are disulfide-rich proteins that contain a combination of a head-to-tail cyclized backbone and a knotted arrangement of three conserved disulfide bonds that make up a cyclic cystine knot motif [63]. Figure 5 displays the crystal structure of cyclotides from Viola tricolor $[18,64]$. Isolated cyclotides exhibited a cytotoxic effect against human cancer cells U251, MDA-MB-231, A549, DU145, and BEL-7402 [63] and the U-937 GTB and RPMI-8226/s cell lines [65]. Cyclotides exhibited anticancer, anti-HIV, or hemolytic activity in vitro [66]. Cyclotides are smaller than most natural proteins, such as nebrodeolysin, and their high stability makes them particularly beneficial to drug design [66].

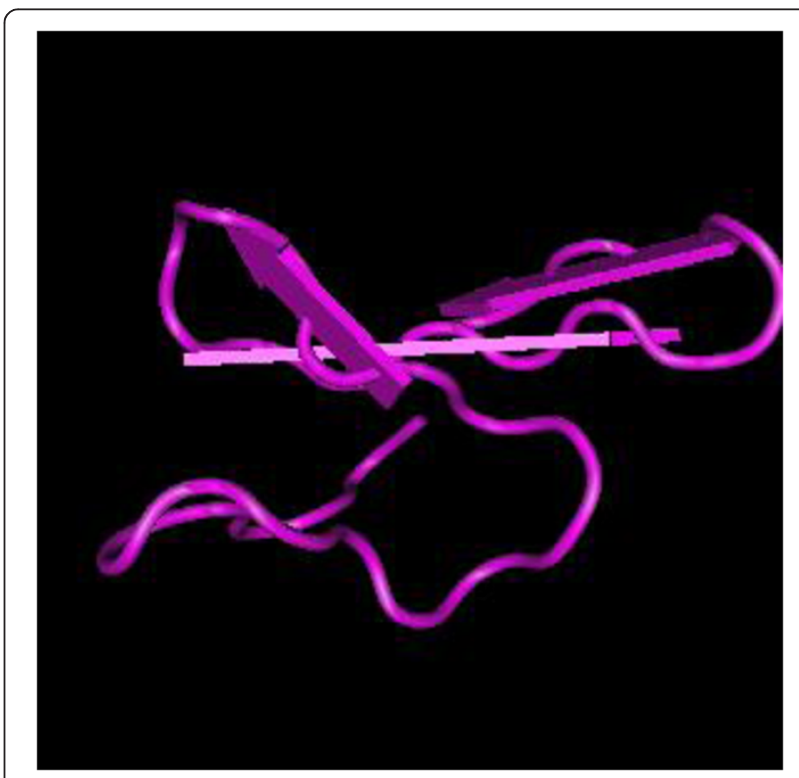

Figure 5 Crystal structure of cyclotides from viola tricolor. 


\section{Cochinin B, MCoCC-1, and McoCl from Momordica cochinchinensis seeds}

The seeds of Momordica cochinchinensis (Mubiezhi) were used as an anti-inflammatory agent to treat hemorrhoids and hemangiomas $[67,68]$. Several bioactive proteins were isolated and purified from $M$. cochinchinensis, including ribosome-inactivating protein cochinin $\mathrm{B}$, peptide $\mathrm{MCoCC}$ 1 , and a chymotrypsin inhibitor McoCI by ammonium sulfate precipitation, cation-exchange chromatography on SP Sepharose column, and size-exclusion chromatography on Superdex 75 column with FPLC [69].

The MCoCC peptides were purified from an extract of dried M. cochinchinensis seeds by a series of RP-HPLC purifications on Phenomenex C18 columns [68]. Similarly, McoCI was isolated from M. cochinchinensis (Lour) seeds by dialysis, chymotrypsin-Sepharose $4 \mathrm{~B}$ column chromatography and reversed-phase HPLC [70].

Cochinin B has a molecular weight of $28 \mathrm{kDa}$ and the N-terminal sequence is DVSFDMSTASTESYKKFIAD, which displays $45-60 \%$ identity to other type I RIPs in the Cucurbitaceae family recorded in GenBank [69]. MCoCC-1 and MCoCC-2, which are approximately $7.5 \mathrm{k} \mathrm{Da}$, have partial sequences of 33 and 32 amino acid residues, respectively, which differ only in two residues. They are also Cysrich peptides with a cystine knot motif [68]. Figure 6 shows the crystal structure of MCoCC-1 from M. cochinchinensis $[18,68]$.

Cochinin B, a ribosome-inactivating protein, exhibited strong anticancer activity against human cervical epithelial carcinoma (HeLa), human embryonic kidney (HEK293), and human small cell lung cancer (NCI-H187) cell lines

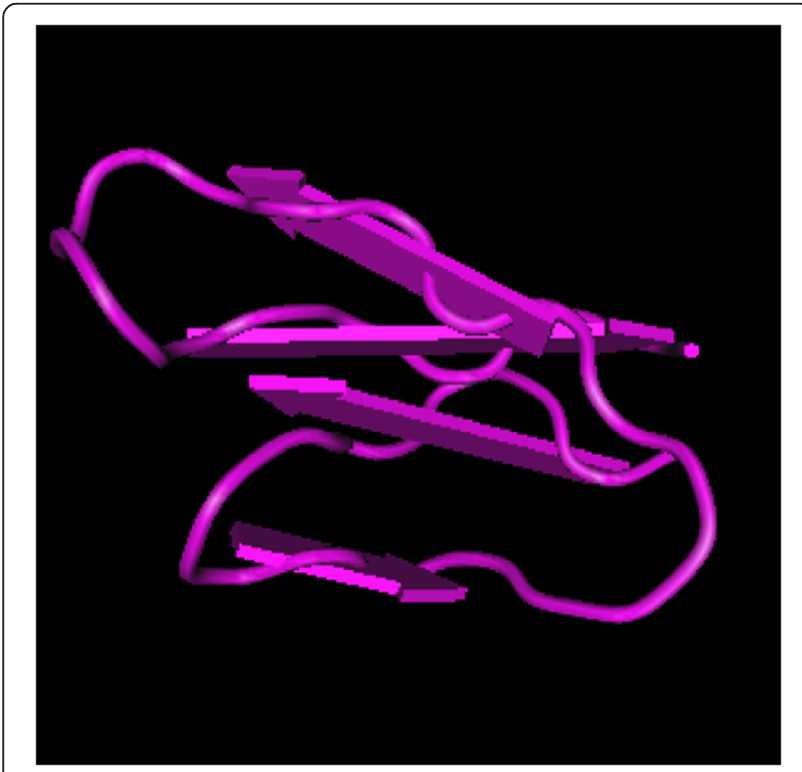

Figure 6 Crystal structure of MCoCC-1 from momordica cochinchinensis.
[69]. MCoCC-1, exhibited cytotoxic effects against human melanoma cell line MM96L and was nonhemolytic [68]. McoCI, a $7.5-\mathrm{kDa}$ antioxidative and immunomodulatory potato I family chymotrypsin inhibitor, reversed oxidative injury in $t$-BHP-challenged rat hepatocytes via the antioxidative activity of glutathione-S-transferase and superoxide dismutase [71]. It stimulated the proliferation of mouse splenocytes, splenic lymphocytes, bone marrow cells, and macrophages, and inhibited $\mathrm{H}_{2} \mathrm{O}_{2}$ production by macrophages and neutrophils [67].

\section{Lectin CM-1 and ACML-55 from Viscum album}

Viscum album (Mistletoe) was used as a complementary anticancer medicinal herb [72]. A mistletoe lectin-I, designated as CM-1, was isolated from the leaves of $V$. album and purified by affinity chromatography and cation-exchange chromatography [73]. ACML-55 was isolated by solvent extraction and purified by CMSepharose column chromatography [74].

CM-1, a 55-kDa lectin, down-regulated micro-RNA miR-135a and miR-b expression, leading to up-regulation of adenomatous polyposis coli gene expression and attenuation of the Wnt pathway in CLY colon cancer cells and HT-29 colorectal cancer cells, both in vivo and in vitro [73]. ACML-55 enhanced both antigen-specific activation and proliferation of $\mathrm{CD}^{+}$and $\mathrm{CD} 8^{+} \mathrm{T}$ cells and a number of tumor antigen-specific $\mathrm{CD}^{+} \mathrm{T}$ cells in colon cancer cell line CT 26 in BALB/c mice [74]. The number of natural killer cells and gamma-delta T cells was also elevated, indicating that ACML-55 modulated innate and adaptive immune responses [74]. The lectin from $V$. album activated autophagy to promote the proliferation of placenta-derived mesenchymal stem cells via upregulation of type II LC3 and downregulation of phosphorylated mTOR [75].

\section{A cholesterol-lowering protein from Senna obtusifolia seed}

Senna obtusifolia seeds (Juemingzi) were used in CM to treat hyperlipidemia and hypertension, and to remove liver heat (gan re) [76,77]. Moreover, a novel cholesterol-lowering protein was isolated and purified from $S$ obtusifolia seeds by gel-filtration and ion-exchange chromatography [78].

This cholesterol-lowering protein is a single protein with a molecular weight of $19.7 \mathrm{kDa}$ and a pI of 4.8 [78]. Nterminal amino acid sequence of this peptide, IPYISASFPLNIEFLPSE, has no homology with any other protein sequences in the GeneBank [78]. Its secondary structure has $12.5 \% \alpha$-helix, 55.6\% $\beta$-sheet, and 31.9\% random coil [78].

This cholesterol-lowering protein inhibited cholesterol biosynthesis in Chinese hamster oocytes [78]. Statins were commonly used as HMG-CoA reductase inhibitors to reduce the blood cholesterol level. However, they had adverse effects, mainly on muscles but occasionally on nonmuscle 
tissue [79]. Thus, the hyperlipidemic mechanism and safety of the novel protein from Juemingzi must be thoroughly evaluated.

\section{Lectin (NTL) from Narcissus tazetta var. chinensis}

Narcissus tazetta var. chinensis was an anticancer medicinal herb. N. tazetta lectin, (NTL) was isolated and purified by various chromatographies, including ion- exchange chromatography on diethylaminoethyl (DEAE)-cellulose, affinity chromatography on mannose-agarose, and FPLCgel filtration on Superose 12 [80].

NTL has a molecular weight of $26 \mathrm{kDa}$, and is probably a dimer with two identical subunits. NTL protein, predicted by cDNA sequence, contains a mature polypeptide and a C-terminal peptide extension [80]. Moreover, NTL primary polypeptide contains three subdomains, each with a conserved mannose-binding site. NTL is $60-80 \%$ identical to other known monocot mannose-binding lectins [80].

NTL inhibited plaque formation from human syncytial virus (RSV) and antiviral properties against influenza A and B [80]. NTL exhibited an immunopotentiating effect, similar to that of LZ-8, by inducing gene expression of IL- $1 \beta$, TNF- $\alpha$, and nitric oxide synthase in splenocytes and macrophages in vivo [81].

\section{Smilaxin from Smilax glabra rhizomes}

Smilax glabra rhizomes (Tufuling) had antipyretic, detoxifying, and diuretic effects and were used in the treatment of brucellosis, syphilis, furunculosis, eczema, dermatitis, nephritis, cystitis, and mercury and silver poisoning [82]. Smilaxin was isolated from fresh S. glabra by successive column chromatography on DEAE-cellulose, CM-cellulose, Con A-Sepharose, and Mono S, and FPLCgel filtration on Superdex 75 [83]. Smilaxin is a $30-\mathrm{kDa}$ protein, and the N-terminal sequence of smilaxin is homologous to few proteins [83].

Smilaxin exhibited immunostimulatory, antiproliferative, and HIV-1-reverse transcriptase inhibitory activities [83]. Smilaxin specifically stimulated the uptake of $\left[\right.$ methyl $^{3} \mathrm{H}$ ] thymidine in murine splenocytes, peritoneal macrophages, and bone marrow cells, but not in MBL2 or PU5 tumor cells [83]. It also attenuated the activity of HIV-1 reverse transcriptase with an IC50 of $5.6 \mu \mathrm{M}$ [83].

\section{Ginkbilobin from Ginkgo biloba seeds}

Ginkgo biloba seeds were used in CM for relieving cough and asthma, reducing phlegm, and leukorrhea, and treating incontinence [84]. Ginkbilobin was isolated and purified from G. biloba seeds by dialysis, DEAEcellulose column chromatography, Affi-gel blue gel chromatography, ion-exchange chromatography, and FPLC-gel filtration [85]. Purified Ginkbilobin-2 was obtained by Sephadex G-50 column and ion-exchange chromatography [86].
Both ginkbilobin and ginkbilobin-2, are $~ 13-k D a$ proteins with 108 amino acids, which is the product of a propeptide containing 134 amino acids and a potential signal peptide ( 26 residues) with approximately $85 \%$ identity to embryo-abundant proteins from Picea abies and Picea glauca [87]. The differences in amino acid sequence between ginkbilobin and ginkbilobin-2 are His10/Cys, Ala17/ Ser, Ala19/Ser, Ala36/Thr, and Ala39/Ser. Ginkbilobin has two $\alpha$-helices and a five-stranded $\beta$-sheet, which form a compact single-domain architecture with an $\alpha+\beta$-fold. The crystal structure of Ginkbilobin-2 was shown in Figure 7 [18,88]. The positively charged surface of ginkbilobin-2 might react with the negatively charged surface of fungal cells to display its antifungal activity [87].

Ginkbilobin exhibited antifungal activity against Botrytis cinerea, Mycosphaerella arachidicola, Fusarium oxysporum, Rhizoctonia solani, and Coprinus comatus and antibacterial activity against Staphylococcus aureus, Pseudomonas aeruginosa, and Escherichia coli [85]. In addition, it inhibited HIV-1 reverse transcriptase and proliferation of murine splenocytes [85]. The pharmacology of ginkbilobin-2 should be studied in the future.

\section{Dioscorin from Dioscorea batatas}

Tubers from the Dioscorea genus were widely used in CM to relieve the menopausal syndrome [89]. A tuber storage protein from Dioscorea batatas, dioscorin, was isolated and purified by ammonium sulfate fractionation, DE-52 ion-exchange chromatography, and Sephadex G-75 column chromatography [90].

Dioscorea batatas dioscorin, a 32-kDa protein, protect against airway damage due to the trypsin activity of dust

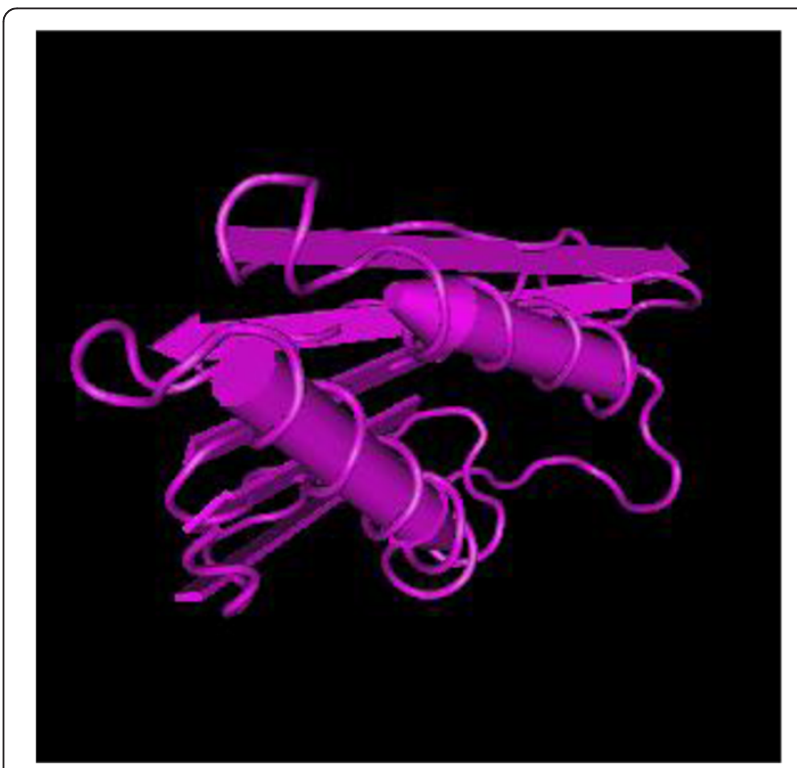

Figure 7 Crystal structure of Ginkbilobin-2 of Ginkgo biloba seeds. 


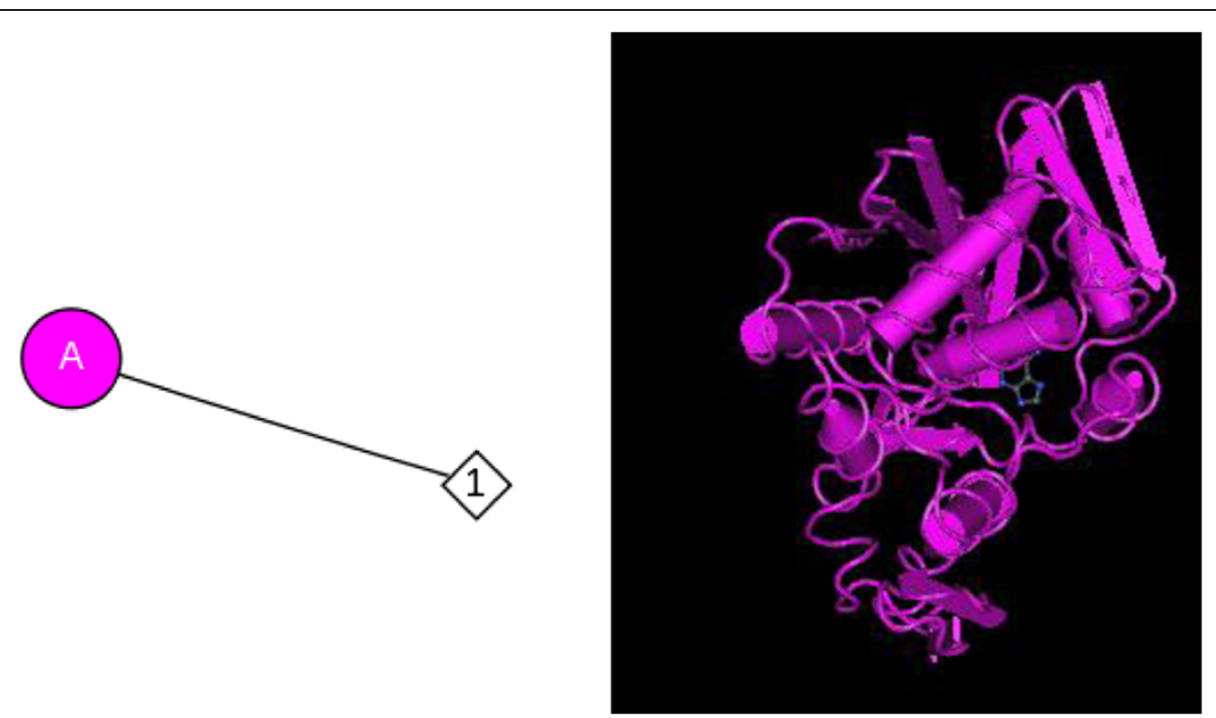

Figure 8 Crystal structure of the complex of trichosanthin of Trichosanthes kirilowii with adenine. A stands for chain of trichosanthin; 1 represents adenine.

mites by reversing the expression of tight junction proteins [90]. It prevented hydrogen peroxide-induced oxidative damage via down regulating IL-8 secretion and adhesion molecule expressions, and possibly activating IкB in A549 human airway epithelial cells [91,92]. Dioscorin also scavenged 1,1-diphenyl-2-picrylhydrazyl radicals and capture hydroxyl radicals, indicating it had antioxidant properties [93]. The immunomodulatory properties of dioscorin included stimulation of cytokine production and nitric oxide production, RAW 264.7 phagocytosis of E. coli, and mitogenic effects on mouse splenocytes [94]. These properties were indicated by in vivo data from dioscorin-treated $\mathrm{BALB} / \mathrm{c}$ mice [95].

\section{Trichosanthin from Trichosanthes kirilowii}

The root of Trichosanthes kirilowii was used in CM for treating lung heat (fei re) and inflammation [96]. A trichosanthin (TCS) was isolated from T. kirilowii root tubers by acetone fractionation and CM-Sepharose ion-exchange chromatography [97]. Recently, Arijit Mondal extracted and purified TCS with three-phase partitioning (TPP), which was cost-effective and environmental friendly [98].

TCS is a single-chain $24-\mathrm{kDa}$ protein with 247 amino acid residues including a 23 -amino acid $\mathrm{N}$-terminal signal peptide and a 19 -amino acid C-terminal pro-peptide [99-101]. TCS contains $12.2 \% \alpha$-helices, $16.3 \%$, $\beta$-sheets, $51.4 \%$ turns, and $20.1 \%$ random curls. TCS is a type I ribosome-inactivating protein, which inactivated ribosomes by site-specific cleavage of the single $\mathrm{N}-\mathrm{C}$ glycosidic bond and prevented the elongation factor from binding to the $60 \mathrm{~S}$ ribosomal subunit, resulting in arrest of protein synthesis [102]. The mature protein is homologous to other ribosome-inactivating proteins (RIPs).
The peptide SDDDMGFGLFD is related to the conserved C-terminal elongation factor binding zone of the ribosomal P protein and is similar to ricin A [103]. Additionally, the crystal structure of the complex of trichosanthin with adenine was shown in Figure $8[18,104]$.

Isoforms of TCS, $\alpha$-, $\beta$ - and $\gamma$-TCS, with similar biochemical activities have been reported [105]. Also, Wang et al. [106,107] constructed two mutants of TCS, RL2829CG and FYY163-165CSA in E.coli. TCS lowered serum HIV-1 p24 antigen levels and increased CD4 $4^{+} \mathrm{T}$ cell number in HIV-1 infected patients [108,109]. TCS also inhibited hepatitis B virus and tumor growth $[110,111]$. Additionally, TCS exhibited anti-cancer effects. TCS promoted breast cell cancer cell line apoptosis in vitro and in nude mice [112], and inhibited tumour migration in vitro and angiogenesis in the aortic ring model without side effects [113]. TCS inhibited lung cancer proliferation and induced apoptosis, and also enhanced the immunoreaction by increasing the expression and interaction of tumor suppressor in lung cancer 1 (TSLC1) and class I-restricted T cell-associated molecule (CRTAM) [114]. TCS suppressed nasopharyngeal carcinomas via inhibiting Notch signaling and proliferation in vitro [115], as well as induced cell death and inhibited telomerase activity in nude mice [116]. Moreover, TCS possessed anti-HSV-1 property in human epithelial carcinoma cell line HEp-2 via type II apoptotic signaling after infection [117], and inhibiting the activation of NF- $\mathrm{kB}$ and inducing p53-dependent apoptosis [118]. TCS was used to successfully cure $85 \%$ of 140 cases of ectopic pregnancy with higher beta-human chorionic gonadotropin [119].

TCS has limited clinical applications due to its major adverse effects, including short plasma half-life, immunogenicity, 
and neurotoxicity [120,121]. However, TCS exhibited less cytotoxicity than type II ribosome-inactivating proteins, including abrin, ricin, etc. [120]. Researchers employing recent advances in drug delivery technology have reported that site-directed PEGylation of trichosanthin could decrease immunogenicity, and prolong plasma half-life [7].

\section{Future development}

Research of bioactive proteins and peptides in CM is still in the early stage of development. A number of them have been isolated and characterized, but only a few are commercially available as pharmaceuticals, such as Hirudin. Advances in technologies would facilitate development of protein pharmaceuticals in CM. Approaches to discovery of the action mechanisms of proteins from CM would be crucial to translate $\mathrm{CM}$ protein in synergistic proportions into pharmaceutical for clinical use.

\section{Conclusion}

The bioactive proteins and peptides isolated from $\mathrm{CM}$ have therapeutic potentials but further study and pharmaceutical development would be necessary for clinical use.

\begin{abstract}
Abbreviations
CINAHL Plus: Cumulative Index to Nursing \& Allied Health Plus; CNKI: China National Knowledge Infrastructure; CQVIP: Chongqing VIP Information; CJFD: China Academic Journals Full-text Database; WHO: World Health Organization; MMDB: Molecular Modeling Database; CDD: Conserved Domain Database; NCBI: National Center for Biotechnology Information; AEP: anti-epilepsy protein; CM: Chinese medicine; CML: Cordyceps militaris Lectin; CMP: Cordyceps militaris protease; EFE: earthworm fibrinolytic enzyme; FDA: Food and Drug Administration; FPLC: Fast protein liquid chromatography; GCL: Ganoderma capense lectin; LZ-8: Ling Zhi-8 protein; NTL: Narcissus tazetta lectin; PCP: Poria cocos immunomodulatory protein; PEG: polyethylene glycol; TCS: trichosanthin; VTCs: Viola tricolor cyclotides.
\end{abstract}

\section{Competing interests}

The authors declare that they have no competing interests.

\section{Authors' contributions}

SCWS, YBZ, ZJZ, and YT designed and conceived the study. SCWS, RNSW, WKL, TBN and PCS, select and organize the contents of manuscript. KLW, LZ, HPC, and JL wrote the manuscript. TBN, PCLK and YML provided the constructive comments and re-wrote parts of manuscript. All authors read and approved the final version of the manuscript.

\section{Acknowledgments}

This study was partially supported by grants from the Innovation and Technology Fund (ITF), project no ITS/262/09FP, of the Innovation and Technology Commission, Government of Hong Kong Special Administrative Region; and Seed Funding Programme for Basic Research, Project codes: 200707176177, 201011159213 and 201111159222, the University of Hong Kong. We also thank our ITF sponsors, including Oriental International Health Products Company Limited, and Hong Kong Ma Sai Leung Tong Medicine Manufacturing Limited, which are our collaborating organizations in the Innovation and Technology project.

\section{Author details}

${ }^{1}$ School of Chinese Medicine, LKS Faculty of Medicine, The University of Hong Kong, 10 Sassoon Road, Pokfulam, Hong Kong Special Administrative Region, China. ${ }^{2}$ Department of Biology, Faculty of Science, Hong Kong Baptist University, Hong Kong Special Administrative Region, China. ${ }^{3}$ School of Biomedical Sciences, Faculty of Medicine, The Chinese University of Hong
Kong, Shatin, N.T., Hong Kong Special Administrative Region, China. ${ }^{4}$ School of Life Sciences and Centre for Protein Science and Crystallography, Faculty of Science, The Chinese University of Hong Kong, Shatin, N.T., Hong Kong Special Administrative Region, China. ${ }^{5}$ Department of Pharmacology \& Pharmacy, LKS Faculty of Medicine, The University of Hong Kong, Pokfulam, Hong Kong Special Administrative Region, China. ${ }^{6}$ Department of Health Technology and Informatics, Hong Kong Polytechnic University, Hung Hom, Hong Kong Special Administrative Region, China.

Received: 18 March 2011 Accepted: 4 July 2014

Published: 19 July 2014

\section{References}

1. Global markets and manufacturing technologies for protein drugs. [http://www.bccresearch.com/market-research/biotechnology/proteindrugs-therapeutics-bio021d.html]

2. Sheremata WA, Minagar A, Alexander JS, Vollmer T: The role of alpha-4 integrin in the aetiology of multiple sclerosis: current knowledge and therapeutic implications. CNS Drugs 2005, 19:909-922.

3. Zhou N, Bao Y, Zhang HA: Clinical analysis of intravenous urokinase treatment of 10 cases with Kawasaki disease complicated with thrombus in coronary aneurysm. Zhonghua Er Ke Za Zhi 2009, 47:384-385.

4. Lequerré T, Quartier P, Rosellini D, Alaoui F, De Bandt M, Mejjad O, Kone-Paut I, Michel M, Dernis E, Khellaf M, Limalet N, Job-Deslandre C, Fautrel B, Le Loët X, Sibilia J: Interleukin-1 receptor antagonist (anakinra) treatment in patients with systemic-onset juvenile idiopathic arthritis or adult onset Still disease: preliminary experience in France. Ann Rheum Dis 2008, 67:302-308.

5. Wang M, Lamers RJ, Korthout HA, van Nesselrooij JH, Witkamp RF, van der Heijden R, Voshol PJ, Havekes LM, Verpoorte R, van der Greef J: Metabolomics in the context of systems biology: bridging traditional Chinese medicine and molecular pharmacology. Phytother Res 2005, 19:173-182.

6. Quality control of protein therapeutics: ICH guideline Q6B. [http://www. pharmaceutical-int.com/article/protein-therapeutics-ich-guideline-q6b.html]

7. An Q, Lei Y, Jia N, Zhang X, Bai Y, Yi J, Chen R, Xia A, Yang J, Wei S, Cheng X, Fan A, Mu S, Xu Z: Effect of site-directed PEGylation of trichosanthin on its biological activity, immunogenicity, and pharmacokinetics. Biomol Eng 2007, 24:643-649.

8. Slowing II, Vivero-Escoto JL, Wu CW, Lin VSY: Mesoporous silica nanoparticles as controlled release drug delivery and gene transfection carriers. Adv Drug Deliv Rev 2008, 60:1278-1288.

9. Fu Z, Zhang L, Liu X, Zhang Y, Zhang Q, Li X, Zheng W, Sun L, Tian J: Comparative proteomic analysis of the sun- and freeze-dried earthworm Eisenia fetida with differentially thrombolytic activities. J Proteomics 2013, 83:1-14.

10. Chen LY, Zhang Y, Qi F, Song FT, Wang WM: Compared with the dissolubility proteins and activity of fibrinolytic enzyme between fresh earthworm and Dry earthworm. Chin J Exp Trad Med Formulae 2012, 18(8):89-92.

11. Liang JQ, Mi SQ, Wang NS: Anticoagulative effect and antiplatelet aggregation effect of combination of Hirudo and Tabanus on rat model of blood stasis syndrome. Zhong Yao Cai 2009, 32:1347-1350.

12. Fenton JW 2nd, Ofosu FA, Brezniak DV, Hassouna HI: Thrombin and antithrombotics. Semin Thromb Hemost 1998, 24:87-91.

13. Rydel TJ, Tulinsky A, Bode W, Huber R: Refined structure of the hirudin-thrombin complex. J Mol Biol 1991, 221:583-601.

14. Tanaka-Azevedo AM, Morais-Zani K, Torquato RJ, Tanaka AS: Thrombin inhibitors from different animals. J Biomed Biotechnol 2010, 2010:641025.

15. Badziong W, Crause P, Habermann P, Tripier D: Process for the isolation and purification of hirudin. U.S. Patent No. 5,095,092. Washington, DC: U.S. Patent and Trademark Office; 1992.

16. Folkers PJM, Clore GM, Driscoll PC, Dodt J, Kohler S, Gronenborn AM: Solution structure of recombinant hirudin and the Lys-47-]Glu mutant - a nuclear magnetic-resonance and hybrid distance geometry dynamical simulated annealing study. Biochemistry 1989, 28:2601-2617.

17. Haruyama $\mathrm{H}$, Wuthrich $\mathrm{K}$ : Conformation of recombinant desulfatohirudin in aqueous-solution determined by nuclear magnetic-resonance. Biochemistry 1989, 28:4301-4312.

18. Madej T, Addess KJ, Fong JH, Geer LY, Geer RC, Lanczycki CJ, Liu CL, Lu SN, Marchler-Bauer A, Panchenko AR, Chen J, Thiessen PA, Wang YL, Zhang DC, 
Bryant SH: MMDB: 3D structures and macromolecular interactions. Nucleic Acids Research 2012, 40:D461-D464.

19. Brenner P, Keller M, Beiras-Fernandez A, Uchita S, Kur F, Thein E, Wimmer C, Hammer C, Schmoeckel M, Reichart B: Prevention of hyperacute xenograft rejection through direct thrombin inhibition with hirudin. Ann Transplant 2010, 15:30-37.

20. Warkentin TE: Bivalent direct thrombin inhibitors: hirudin and bivalirudin. Best Pract Res Clin Haematol 2004, 17:105-125.

21. Bjork I, Lindahl U: Mechanism of the anticoagulant action of heparin. Mol Cell Biochem 1982, 48:161-182.

22. Kashyap VS, Bishop PD, Bena JF, Rosa K, Sarac TP, Ouriel K: A pilot, prospective evaluation of a direct thrombin inhibitor, bivalirudin (Angiomax), in patients undergoing lower extremity bypass. J Vasc Surg 2010, 52:369-374.

23. Warkentin TE, Greinacher A, Koster A: Bivalirudin. Thromb Haemost 2008 , 99:830-839.

24. Jiang SY, Jiao J, Zhang TT, Xu YP: Pharmacokinetics study of recombinant hirudin in the plasma of rats using chromogenic substrate, ELISA, and radioisotope assays. PLoS One 2013, 8:e64336.

25. Huang X-I, CAl J, Su C-W, Pan F-Z, Liao C-f, Li L-m: Experimental observation of hirudin combined with adriamycin on resistance of human ovarian cancer cell line. J Snake 2013, 4:002

26. Bin $\mathrm{H}$, Chengwu S, Jie C, Guogian Y, Weiguan Z: Mechanisms of hirudin combined with adriamycin on anti-proliferation of tongue squamous cell carcinoma line TCA8113 [J]. Modern J Int Trad Chin Western Med 2011, 12:009.

27. Jia A, Zhang H, Bao F, Wang Z-h, LIU Y, YAO W: Effects of hirudin on histone $\mathrm{H} 1$ expressions in mice bearing hepatocarcinoma $\mathrm{H} 22$ cells-derived tumor. Eval Anal Drug-Use Hospitals China 2011, 11:1008-1010.

28. Paoletti MG: Ecological Implications of Minilivestock: Potential of Insects, Rodents, Frogs and Snails. Enfield: Science Publishers, Inc; 2005

29. Wang KY, Tull L, Cooper E, Wang N, Liu DH: Recombinant Protein Production of Earthworm Lumbrokinase for Potential Antithrombotic Application. Evid base Compl Alternative Med 2013, 2013:783971.

30. Wang F, Wang C, Li M, Gui LL, Zhang JP, Chang WR: Purification, characterization and crystallization of a group of earthworm fibrinolytic enzymes from Eisenia fetida. Biotechnol Lett 2003, 25:1105-1109.

31. Tang Y, Liang DC, Jiang T, Zhang JP, Gui LL, Chang WR: Crystal structure of earthworm fibrinolytic enzyme component $A$ : Revealing the structural determinants of its dual fibrinolytic activity. J Mol Biol 2002, 321:57-68.

32. Wang F, Wang C, Li M, Zhang JP, Gui LL, An XM, Chang WR: Crystal structure of earthworm fibrinolytic enzyme component B: a novel, glycosylated two-chained trypsin. J Mol Biol 2005, 348:671-685.

33. Chen H, Takahashi S, Imamura M, Okutani E, Zhang ZG, Chayama K, Chen BA: Earthworm fibrinolytic enzyme: anti-tumor activity on human hepatoma cells in vitro and in vivo. Chin Med J (Engl) 2007, 120:898-904.

34. Zhao J, Qi S-P, Wu J, Li L, He R-Q: Earthworm fibrinolytic enzyme. Stud Nat Prod Chem 2005, 30:825-847.

35. Nakajima N, Ishihara K, Sugimoto M, Sumi H, Mikuni K, Hamada H: Chemical modification of earthworm fibrinolytic enzyme with human serum albumin fragment and characterization of the protease as a therapeutic enzyme. Biosci Biotechnol Biochem 1996, 60:293-300.

36. Ricotti V, Delanty N: Use of complementary and alternative medicine in epilepsy. Curr Neurol Neurosci Rep 2006, 6:347-353.

37. Zhou XH, Yang D, Zhang JH, Liu CM, Lei KJ: Purification and N-terminal partial sequence of anti-epilepsy peptide from venom of the scorpion Buthus martensii Karsch. Biochem J 1989, 257:509-517.

38. Wang CG, He XL, Shao F, Liu W, Ling MH, Wang DC, Chi CW: Molecular characterization of an anti-epilepsy peptide from the scorpion Buthus martensi Karsch. Eur J Biochem 2001, 268:2480-2485.

39. Wang Z, Wang W, Shao Z, Gao B, Li J, Ma J, Che H, Zhang W: Eukaryotic expression and purification of anti-epilepsy peptide of Buthus martensii Karsch and its protein interactions. Mol Cell Biochem 2009, 330:97-104.

40. Wang Y, Wang L, Cui Y, Song YB, Liu YF, Zhang R, Wu CF, Zhang JH: Purification, characterization and functional expression of a new peptide with an analgesic effect from Chinese scorpion Buthus martensii Karsch (BmK AGP-SYPU1). Biomed Chromatogr 2011, 25:801-807.

41. Marchler-Bauer A, Zheng CJ, Chitsaz F, Derbyshire MK, Geer LY, Geer RC, Gonzales NR, Gwadz M, Hurwitz DI, Lanczycki CJ, Lu F, Lu SN, Marchler GH, Song JS, Thanki N, Yamashita RA, Zhang DC, Bryant SH: CDD: conserved domains and protein three-dimensional structure. Nucleic Acids Research 2013, 41:D348-D352.
42. Wong JH, Ng TB, Wang H, Sze SC, Zhang KY, Li Q, Lu X: Cordymin, an antifungal peptide from the medicinal fungus Cordyceps militaris. Phytomedicine 2011, 18:387-392.

43. Jung EC, Kim KD, Bae CH, Kim JC, Kim DK, Kim HH: A mushroom lectin from ascomycete Cordyceps militaris. Biochim Biophys Acta 2007, 1770:833-838.

44. Park BT, Na KH, Jung EC, Park JW, Kim HH: Antifungal and anticancer activities of a protein from the mushroom cordyceps militaris. Korean $J$ Physiol Pharmacol 2009, 13:49-54

45. Qi W, Zhang Y, Yan YB, Lei W, Wu ZX, Liu N, Liu S, Shi L, Fan Y: The Protective Effect of Cordymin, a Peptide Purified from the Medicinal Mushroom Cordyceps sinensis, on Diabetic Osteopenia in Alloxan-Induced Diabetic Rats. Evid base Compl Alternative Med 2013, 2013:985636.

46. Paterson RR: Ganoderma - a therapeutic fungal biofactory. Phytochemistry 2006, 67:1985-2001.

47. Pharmacopoeia of People's Republic of China, vol. 1, 2010. In Edited by Commission CP. Beijing: Chinese Medical Science and Technology Press; 2010:174-175

48. Zhou X, Lin J, Yin Y, Zhao J, Sun X, Tang K: Ganodermataceae: natural products and their related pharmacological functions. Am J Chin Med 2007, 35:559-574.

49. Tanaka S, Ko K, Kino K, Tsuchiya K, Yamashita A, Murasugi A, Sakuma S, Tsunoo H: Complete amino acid sequence of an immunomodulatory protein, ling zhi-8 (LZ-8). An immunomodulator from a fungus, Ganoderma lucidium, having similarity to immunoglobulin variable regions. J Biol Chem 1989, 264:16372-16377

50. Murasugi A, Tanaka S, Komiyama N, Iwata N, Kino K, Tsunoo H, Sakuma S: Molecular cloning of a cDNA and a gene encoding an immunomodulatory protein, Ling Zhi-8, from a fungus, Ganoderma lucidum. J Biol Chem 1991, 266:2486-2493.

51. Huang L, Sun F, Liang C, He YX, Bao R, Liu L, Zhou CZ: Crystal structure of LZ-8 from the medicinal fungus Ganoderma lucidium. Proteins 2009, 75:524-527.

52. Lin YL, Liang YC, Tseng YS, Huang HY, Chou SY, Hseu RS, Huang CT, Chiang BL: An immunomodulatory protein, Ling Zhi-8, induced activation and maturation of human monocyte-derived dendritic cells by the NF-kappaB and MAPK pathways. J Leukoc Bio/ 2009, 86:877-889.

53. Yeh $\mathrm{CH}$, Chen HC, Yang JJ, Chuang WI, Sheu F: Polysaccharides PS-G and protein LZ-8 from Reishi (Ganoderma lucidum) exhibit diverse functions in regulating murine macrophages and T lymphocytes. J Agric Food Chem 2010, 58:8535-8544.

54. Ngai PH, Ng TB: A mushroom (Ganoderma capense) lectin with spectacular thermostability, potent mitogenic activity on splenocytes, and antiproliferative activity toward tumor cells. Biochem Biophys Res Commun 2004, 314:988-993.

55. Lin CC, Yu YL, Shih CC, Liu KJ, Ou KL, Hong LZ, Chen JD, Chu CL: A novel adjuvant Ling Zhi-8 enhances the efficacy of DNA cancer vaccine by activating dendritic cells. Cancer Immunol Immunother 2011, 60:1019-1027.

56. Wu CT, Lin TY, Hsu HY, Sheu F, Ho CM, Chen El: Ling Zhi-8 mediates p53-dependent growth arrest of lung cancer cells proliferation via the ribosomal protein S7-MDM2-p53 pathway. Carcinogenesis 2011, 32:1890-1896.

57. Liang CY, Li HR, Zhou H, Zhang SQ, Liu ZY, Zhou QL, Sun F: Recombinant Lz-8 from Ganoderma lucidum induces endoplasmic reticulum stressmediated autophagic cell death in SGC-7901 human gastric cancer cells. Oncol Rep 2012, 27:1079-1089.

58. Zhou H, Sun F, Li HR, Zhang SQ, Liu ZY, Pei J, Liang CY: Effect of recombinant Ganoderma lucidum immunoregulatory protein on cyclophosphamide-induced leukopenia in mice. Immunopharmacol Immunotoxicol 2013, 35:426-433.

59. Zhang M, Gao XH, Sun XM, Xu XT, Li XY, Shi YJ, Fan XT: Pharmacological Mechanisms and Advancement of Poria cocos. J Beihua Univ (Natural Science Edition) 2008, 9:63-67.

60. Chang $\mathrm{HH}$, Yeh $\mathrm{CH}$, Sheu F: A novel immunomodulatory protein from Poria cocos induces Toll-like receptor 4-dependent activation within mouse peritoneal macrophages. J Agric Food Chem 2009, 57:6129-6139.

61. Lu YT, Kuan YC, Chang HH, Sheu F: Molecular cloning of a poria cocos protein that activates Th1 immune response and allays Th2 cytokine and IgE production in a murine atopic dermatitis model. J Agric Food Chem 2014, 62:2861-2871.

62. State Administration of Traditional Chinese Medicine of the People's Republic of China ZhongHua Bencao. ShangHai: Shanghai Science and Technology Press; 1999:469-470. 
63. Tang J, Wang CK, Pan X, Yan H, Zeng G, Xu W, He W, Daly NL, Craik DJ, Tan N: Isolation and characterization of cytotoxic cyclotides from Viola tricolor. Peptides 2010, 31:1434-1440.

64. Mulvenna JR, Sando L, Craik DJ: Processing of a $22 \mathrm{kDa}$ precursor protein to produce the circular protein tricyclon A. Structure 2005, 13:691-701.

65. Svangard E, Goransson U, Hocaoglu Z, Gullbo J, Larsson R, Claeson P, Bohlin L: Cytotoxic cyclotides from Viola tricolor. J Nat Prod 2004, 67:144-147.

66. Henriques ST, Craik DJ: Cyclotides as templates in drug design. Drug Discov Today 2010, 15:57-64.

67. Tsoi AY, Ng TB, Fong WP: Immunomodulatory activity of a chymotrypsin inhibitor from Momordica cochinchinensis seeds. J Pept Sci 2006, 12:605-611.

68. Chan LY, Wang CK, Major JM, Greenwood KP, Lewis RJ, Craik DJ, Daly NL: Isolation and characterization of peptides from Momordica cochinchinensis seeds. J Nat Prod 2009, 72:1453-1458.

69. Chuethong J, Oda K, Sakurai H, Saiki I, Leelamanit W: Cochinin B, a novel ribosome-inactivating protein from the seeds of Momordica cochinchinensis. Biol Pharm Bull 2007, 30:428-432.

70. Tsoi AY, Wong RC, Ng TB, Fong WP: First report on a potato I family chymotrypsin inhibitor from the seeds of a Cucurbitaceous plant, Momordica cochinchinensis. Biol Chem 2004, 385:185-189.

71. Tsoi AY, Ng TB, Fong WP: Antioxidative effect of a chymotrypsin inhibitor from Momordica cochinchinensis (Cucurbitaceae) seeds in a primary rat hepatocyte culture. J Pept Sci 2005, 11:665-668.

72. Kong JL, Du XB, Fan CX, Zhang JP, Liu SL: Gene cloning and sequencing of a chain of a novel mistletoe protein. J Med Mol Biol 2005, 2:403-408

73. Li LN, Zhang HD, Zhi R, Yuan SJ: Down-regulation of some miRNAs by degrading their precursors contributes to anti-cancer effect of mistletoe lectin-I. Br J Pharmacol 2011, 162:349-364.

74. Ma YH, Cheng WZ, Gong F, Ma AL, Yu QW, Zhang JY, Hu CY, Chen XH, Zhang DQ: Active Chinese mistletoe lectin-55 enhances colon cancer surveillance through regulating innate and adaptive immune responses. World J Gastroenterol 2008, 14:5274-5281.

75. Choi JH, Lyu SY, Lee HJ, Jung J, Park WB, Kim GJ: Korean mistletoe lectin regulates self-renewal of placenta-derived mesenchymal stem cells via autophagic mechanisms. Cell Prolif 2012, 45:420-429.

76. Patil UK, Saraf S, Dixit VK: Hypolipidemic activity of seeds of Cassia tora Linn. J Ethnopharmacol 2004, 90:249-252.

77. Choi JS, Lee HJ, Park KY, Ha JO, Kang SS: In vitro antimutagenic effects of anthraquinone aglycones and naphthopyrone glycosides from Cassia tora. Planta Med 1997, 63:11-14.

78. Li C, Li M, Chang W, Guo B: Purification and characterization of a novel cholesterol-lowering protein from the seeds of Senna obtusifolia. Sci China C Life Sci 2008, 51:1020-1024.

79. Golomb BA, Evans MA: Statin adverse effects : a review of the literature and evidence for a mitochondrial mechanism. Am J Cardiovasc Drugs 2008, 8:373-418

80. Ooi LS, Ho WS, Ngai KL, Tian L, Chan PK, Sun SS, Ooi VE: Narcissus tazetta lectin shows strong inhibitory effects against respiratory syncytial virus, influenza A (H1N1, H3N2, H5N1) and B viruses. J Biosci 2010, 35:95-103.

81. Ooi LS, Liu F, Ooi VE, Ng TB, Fung MC: Gene expression of immunomodulatory cytokines induced by Narcissus tazetta lectin in the mouse. Biochem Cell Biol 2002, 80:271-277.

82. Cheung SC, Li NH: Chinese Medicinal Herbs of Hong Kong. Hong Kong: Commercial Press; 1997.

83. Chu KT, Ng TB: Smilaxin, a novel protein with immunostimulatory, antiproliferative, and HIV-1-reverse transcriptase inhibitory activities from fresh Smilax glabra rhizomes. Biochem Biophys Res Commun 2006, 340:118-124.

84. Wang Q, Wen QB: Studies on the chemical ComPosition and pharmacological effects of ginkgo seeds. Modern Food Sci Technol 2006, 22:164-167.

85. Wang $H$, Ng TB: Ginkbilobin, a novel antifungal protein from Ginkgo biloba seeds with sequence similarity to embryo-abundant protein. Biochem Biophys Res Commun 2000, 279:407-411.

86. Sawano Y, Miyakawa T, Yamazaki H, Tanokura M, Hatano K: Purification, characterization, and molecular gene cloning of an antifungal protein from Ginkgo biloba seeds. Biol Chem 2007, 388:273-280.

87. Miyakawa T, Sawano Y, Miyazono K, Hatano K, Tanokura M: Crystallization and preliminary X-ray analysis of ginkbilobin-2 from Ginkgo biloba seeds: a novel antifungal protein with homology to the extracellular domain of plant cysteine-rich receptor-like kinases (vol F63, Pg 737,
2007). Acta Crystallographica Section F-Struct Biol Crystal Commun 2007, 63:899-909.

88. Miyakawa T, Miyazono K, Sawano Y, Hatano K, Tanokura M: Crystal structure of ginkbilobin-2 with homology to the extracellular domain of plant cysteine-rich receptor-like kinases. Proteins 2009, 77:247-251.

89. Wojcikowski K, Wohlmuth H, Johnson DW, Gobe G: Dioscorea villosa (wild yam) induces chronic kidney injury via pro-fibrotic pathways. Food Chem Toxicol 2008, 46:3122-3131.

90. Hou WC, Liu JS, Chen HJ, Chen TE, Chang CF, Lin YH: Dioscorin, the major tuber storage protein of yam (Dioscorea batatas decne) with carbonic anhydrase and trypsin inhibitor activities. J Agric Food Chem 1999, 47:2168-2172.

91. Fu LS, Ko YH, Lin KW, Hsu JY, Chu JJ, Chi CS: Dioscorin protects tight junction protein expression in A549 human airway epithelium cells from dust mite damage. J Microbiol Immunol Infect 2009, 42:457-463.

92. Hsu JY, Chu JJ, Chou MC, Chen YW: Dioscorin Pre-treatment protects A549 human airway epithelial cells from hydrogen peroxide-induced oxidative stress. Inflammation 2013, 36:1013-1019.

93. Hou WC, Lee MH, Chen HJ, Liang WL, Han CH, Liu YW, Lin YH: Antioxidant activities of dioscorin, the storage protein of yam (Dioscorea batatas Decne) tuber. J Agric Food Chem 2001, 49:4956-4960.

94. Liu YW, Shang HF, Wang CK, Hsu FL, Hou WC: Immunomodulatory activity of dioscorin, the storage protein of yam (Dioscorea alata cv. Tainong No. 1) tuber. Food Chem Toxicol 2007, 45:2312-2318.

95. Liu YW, Liu JC, Huang CY, Wang CK, Shang HF, Hou WC: Effects of oral administration of yam tuber storage protein, dioscorin, to BALB/c mice for 21-days on immune responses. J Agric Food Chem 2009, 57:9274-9279.

96. Pharmacopoeia of People's Republic of China: Commission. CP ed, Volume 1. 2010th edition. Beijing: China Medical Science Press; 2010:104.

97. Ng TB, Chan WY, Yeung HW: Proteins with abortifacient, ribosome inactivating, immunomodulatory, antitumor and anti-AIDS activities from Cucurbitaceae plants. Gen Pharmacol 1992, 23:579-590.

98. Mondal A: A novel extraction of trichosanthin from Trichosanthes kirilowii roots using three-phase partitioning and its in vitro anticancer activity. Pharm Biol 2014, 52(6):677-680.

99. Collins EJ, Robertus JD, LoPresti M, Stone KL, Williams KR, Wu P, Hwang K, Piatak M: Primary amino acid sequence of alpha-trichosanthin and molecular models for abrin A-chain and alpha-trichosanthin. J Biol Chem 1990, 265:8665-8669.

100. Zhang JS, Liu WY: The mechanism of action of trichosanthin on eukaryotic ribosomes-RNA N-glycosidase activity of the cytotoxin. Nucleic Acids Res 1992, 20:1271-1275.

101. Lau CK, Wong RN, Lo SC, Kwok F: Refolding of denatured trichosanthin in the presence of GroEL. Biochem Biophys Res Commun 1998, 245:149-154.

102. Fang EF, Ng TB, Shaw PC, Wong RN: Recent progress in medicinal investigations on trichosanthin and other ribosome inactivating proteins from the plant genus Trichosanthes. Curr Med Chem 2011, 18:4410-4417.

103. Too PH, Ma MK, Mak AN, Wong YT, Tung CK, Zhu G, Au SW, Wong KB, Shaw $P C$ : The $C$-terminal fragment of the ribosomal $P$ protein complexed to trichosanthin reveals the interaction between the ribosome-inactivating protein and the ribosome. Nucleic Acids Res 2009, 37:602-610.

104. Gu YJ, Xia ZX: Crystal structures of the complexes of trichosanthin with four substrate analogs and catalytic mechanism of RNA N-glycosidase. Proteins 2000, 39:37-46.

105. Narayanan P, Mak NK, Luong PB, Wong RN: Isolation and characterization of new isoforms of trichosanthin from Trichosanthes kirilowii. Plant Sci 2002, 162:79-85.

106. Wang Y, Shi Y, Liu ZY, Xu ZK, Xu J, Li ZD: [Construction and expression of trichosanthin mutant gene TCS(RL28-29CG) and purification of expressed product]. Xi Bao Yu Fen Zi Mian Yi Xue Za Zhi 2011, 27:392-394.

107. Wang Y, Li YH, Liu ZY, Shi Y, Xu ZK, Xu J, Li ZD: [Construction, expression and purification of trichosanthin mutant gene TCS(FYY163-165CSA);] Xi Bao Yu Fen Zi Mian Yi Xue Za Zhi 2012, 28:583-585.

108. Byers VS, Baldwin PW: Trichosanthin treatment of HIV disease. AIDS 1991 5:1150-1151.

109. Zhou H, Jiao Z, Pan J, Hong J, Tao J, Li N, Zhou Y, Zhang J, Chou KY: Immune suppression via IL-4/IL-10-secreting T cells: a nontoxic property of anti-HIV agent trichosanthin. Clin Immunol 2007, 122:312-322.

110. Shaw PC, Lee KM, Wong KB: Recent advances in trichosanthin, a ribosome-inactivating protein with multiple pharmacological properties. Toxicon 2005, 45:683-689. 
111. Tsao SW, Ng TB, Yeung HW: Toxicities of trichosanthin and alpha-momorcharin, abortifacient proteins from Chinese medicinal plants, on cultured tumor cell lines. Toxicon 1990, 28:1183-1192.

112. Fang $E F$, Zhang $C Z Y$, Zhang $L$, Wong JH, Chan YS, Pan WL, Dan XL, Yin CM, Cho CH, Ng TB: Trichosanthin inhibits breast cancer cell proliferation in both cell lines and nude mice by promotion of apoptosis. PLoS One 2012 7(9):e41592.

113. He D, Jin J, Zheng Y, Bruce IC, Tam S, Ma X: Anti-angiogenesis effect of trichosanthin and the underlying mechanism. Biochem Biophys Res Commun 2013, 430:735-740.

114. Cai YC, Xiong SD, Zheng YJ, Luo FF, Jiang P, Chu YW: Trichosanthin enhances anti-tumor immune response in a murine Lewis lung cancer model by boosting the interaction between TSLC1 and CRTAM. Cell Mol Immunol 2011, 8:359-367.

115. Liu FY, Wang B, Wang ZX, Yu SD: Trichosanthin down-regulates Notch signaling and inhibits proliferation of the nasopharyngeal carcinoma cell line CNE2 in vitro. Fitoterapia 2012, 83:838-842.

116. Kang M, Ou H, Wang R, Liu W, Mao Y, Tang A: Effect of trichosanthin on apoptosis and telomerase activity of nasopharyngeal carcinomas in nude mice. J BUON 2013, 18:675-682

117. He DX, Yau KH, He XH, Shi HJ, Zheng YT, Tam SC: Conversion of trichosanthin-induced CD95 (Fas) type I into type II apoptotic signaling during Herpes simplex virus infection. Mol Immunol 2011, 48:2000-2008.

118. He D, Zheng Y, Tam S: The anti-herpetic activity of trichosanthin via the nuclear factor-kappaB and p53 pathways. Life Sci 2012, 90:673-681.

119. Xiang DJ, Chen LM, Gu JS, Stone P, Chen Q: Trichosanthin, a Chinese medicine for the medical treatment of ectopic pregnancy with high levels of beta-hCG. Reprod Sci 2012, 19:534-538.

120. Puri M, Kaur I, Perugini MA, Gupta RC: Ribosome-inactivating proteins: current status and biomedical applications. Drug Discov Today 2012 17:774-783.

121. Yan $R$, Zhong W, Zhu Y, Zhang $X$ : Trichosanthin-stimulated dendritic cells induce a type 2 helper T lymphocyte response through the OX40 ligand. J Investig Allergol Clin Immunol 2012, 22:491-500.

doi:10.1186/1749-8546-9-19

Cite this article as: Wong et al:: Bioactive proteins and peptides isolated from Chinese medicines with pharmaceutical potential. Chinese Medicine 2014 9:19.

\section{Submit your next manuscript to BioMed Central and take full advantage of:}

- Convenient online submission

- Thorough peer review

- No space constraints or color figure charges

- Immediate publication on acceptance

- Inclusion in PubMed, CAS, Scopus and Google Scholar

- Research which is freely available for redistribution 